\title{
Modulation of the anatomical and physiological responses of in vitro grown Alcantarea imperialis induced by NAA and residual effects of $B A P$
}

\author{
João Paulo Rodrigues Martins ${ }^{1 *}$, Luiz Carlos de Almeida Rodrigues ${ }^{2}$, Thayna dos Santos Silva ${ }^{1}$, \\ Andreia Barcelos Passos Lima Gontijo ${ }^{1}$, Antelmo Ralph Falqueto ${ }^{1}$
}

\begin{abstract}
During in vitro propagation, cytokinins (CKs) and auxins (AUXs), such as 6-benzylaminopurine (BAP) and 1-naphthaleneacetic acid (NAA), are often used to induce adventitious shoots and roots, respectively. However, it is not clear how CKs affect plants over a long period of in vitro propagation as well as the synergy of direct exposure to AUX with previous CK treatments. The aim was to assess the physiological and anatomical responses of Alcantarea imperialis in function of the interaction of both previous BAP treatments and direct NAA exposure during in vitro propagation. Plants previously grown in vitro were transferred to media containing $0,5,10$ or $15 \mu \mathrm{M}$ BAP. After 60 days, the adventitious shoots from each previous BAP treatment were subcultured in media with 0,2 or $4 \mu \mathrm{M}$ NAA. Pigment content, anatomical and growth traits were assessed in the plants from each treatment. Both previous BAP treatments and direct NAA exposure altered the anatomy and pigment contents of plants as well as their growth traits. BAP induced negative effects over the long term on physiological status as well as changed the plants' anatomy. NAA supplementation in the medium can partially reverse the negative effects induced by BAP. The application of $2 \mu \mathrm{M}$ NAA during in vitro rooting improved the plants' quality.
\end{abstract}

Keywords: bromeliad, auxin, cytokinin, physiological disorders, plant anatomy.

\section{Resumo}

Modulação das respostas anatômicas e fisiológicas de Alcantarea imperialis cultivadas in vitro induzidas por ANA e efeitos residuais de BAP

Durante a propagação in vitro, citocininas (CKs) e auxinas (AUXs), como a 6-benzilaminopurina (BAP) e o ácido 1-naftalenacético (ANA), são frequentemente utilizadas para induzir brotos e raízes adventícias. No entanto, não está claro como as CKs afetam as plantas ao longo do período de propagação in vitro, bem como a sinergia da exposição direta à AUX com tratamentos prévios com CK. O objetivo foi avaliar as respostas fisiológicas e anatômicas de Alcantarea imperialis em função da interação dos tratamentos prévios com BAP e da exposição direta à ANA durante a propagação in vitro. Plantas previamente cultivadas in vitro foram transferidas para meios contendo $0,5,10$ ou $15 \mu \mathrm{M}$ de BAP. Após 60 dias, as brotações adventícias de cada tratamento prévio com BAP foram subcultivadas em meios com ANA 0,2 ou $4 \mu \mathrm{M}$. O conteúdo de pigmentos, as características anatômicas e de crescimento foram avaliados nas plantas de cada tratamento. Os tratamentos anteriores com BAP e a exposição direta a ANA alteraram a anatomia e o conteúdo pigmentos das plantas, bem como o crescimento. O BAP induziu efeitos negativos a longo prazo no status fisiológico, bem como mudou a anatomia das plantas. A suplementação de ANA no meio pode reverter parcialmente os efeitos negativos induzidos pelo BAP. A aplicação de $2 \mu \mathrm{M}$ de ANA durante o enraizamento in vitro melhorou a qualidade das plantas.

Palavras-chave: bromélia, auxina, citocinina, distúrbios fisiológicos, anatomia vegetal.

\footnotetext{
${ }^{1}$ Universidade Federal do Espírito Santo (UFES), Departamento de Ciências Agrárias e Biológicas, São Mateus-ES, Brazil. *Corresponding author: jprmartinss@yahoo.com.br

${ }^{2}$ Universidade Federal de Alfenas (UNIFAL), Faculdade de Odontologia, Alfenas-MG, Brazil.
} 


\section{Introduction}

Techniques of in vitro culture allow the large-scale multiplication of several plant species, including bromeliads (Martins et al., 2018a, b; Rosa et al., 2018). Bromeliads have commercial value to the horticultural industry due to their use in landscaping and interior decoration (Silva et al., 2017). Alcantarea imperialis (Carrière) Harms (subfamily Tillandsioideae) is a bromeliad species of ornamental interest. Usually, A. imperialis is propagated by seeds; however, the plants of this species need several decades to reach adulthood. Thus, in vitro propagation can be an important method for large-scale propagation of this bromeliad species.

The in vitro culture of bromeliads normally is divided into steps, such as establishment, multiplication, rooting and acclimatization phases. Two phases are carried out with plant growth regulators (PGRs) such as cytokinins (CKs) and auxins (AUXs), each one performing different physiological functions. CKs are frequently employed during in vitro multiplication and are an important group of PGRs that can modulate several biotechnological processes due to their ability to influence almost all stages of plant development and growth (Bekircan et al., 2018). The most common synthetic CKs used during the in vitro multiplication phase are 6-benzylaminopurine (BAP) and 6-furfurylaminopurine (kinetin - KIN). To induce adventitious shoots in vitro of bromeliad species, the use of BAP has already been documented as the most efficient (Viehmannova et al., 2016; Rosa et al., 2018).

In in vitro culture of bromeliads, the supplementation of AUXs in the medium is also frequently reported (Martins et al., 2018a; Resende et al., 2016). For bromeliads, the employment of AUXs has been combined with CKs during in vitro multiplication or isolated during in vitro rooting (Faria et al., 2018; Martins et al., 2018a). The synergy between the endogenous and exogenous CKs and AUXs is the key for the metabolic activity and cell division, which are later involved in inducing the differentiation of competent cells to promote the growth of new adventitious shoots (Faria et al., 2018). Although exogenous AUX, applied as an isolated PGR, is not often a limiting factor for in vitro rooting of bromeliads, it may have positive effects on their growth traits (Martins et al., 2018a; Viehmannova et al., 2016). In vitro rooting is an essential step in the vegetative propagation of economically important horticultural herbaceous and woody plant species (Mao et al., 2019). Of the exogenous AUXs applied for the in vitro culture of bromeliads, 1-naphthaleneacetic acid (NAA) is the most frequently used (Viehmannova et al., 2016).

During in vitro multiplication of the bromeliad Aechmea blanchetiana, Rosa et al. (2018) verified that BAP supplemented in the medium induced physiological disorders as well as anatomical changes in the plants' leaves. Likewise, use of BAP during in vitro propagation of A. blanchetiana induced long-term physiological defects, even after 120 days without direct exposure to this CK (Martins et al., 2018b). In contrast, direct NAA exposure, applied as an isolated PGR during in vitro rooting, improved the anatomical and physiological quality of $A$. blanchetiana plants, as well as improving their growth rate after the ex vitro transfer (Martins et al., 2018a). Therefore, those studies brought some questions related to how the interaction of BAP and NAA, applied separately during the in vitro multiplication and rooting phases respectively, can influence the anatomical and physiological status of plants. In fact, little is known about the absorption of PGRs in plant tissues and how they affect plants at a deeper level (Koike et al., 2017).

Anatomical studies can be used to assess the effect of in vitro conditions on the success of the transfer to ex vitro conditions (Martins et al., 2016; Martins et al., 2018a, 2018 b; Faria et al., 2018). Analyses of photosynthetic pigment content are also useful to verify the physiological status of plants (Martins et al., 2018b; Janečková et al., 2019). In this respect, chlorophyll content is a good first indicator of photosynthetic potential, and it can be directly related to photosynthetic apparatus performance of in vitro bromeliads (Martins et al., 2018b).

In view of the foregoing, we hypothesized that: (1) the supplementation of BAP can improve the number of adventitious shoots but at the same time can induce anatomical and physiological disorders over a long period of in vitro propagation of A. imperialis; and (2) the employment of NAA can reverse the negative effects induced by BAP. Therefore, the aim of this study was to analyze the residual effects of BAP after 120 days without its direct exposure, besides to assess physiological and anatomical responses of $A$. imperialis in function of interaction of both previous BAP treatments and direct NAA exposure during in vitro propagation.

\section{Materials and methods}

\section{In vitro multiplication}

Alcantarea imperialis plants previously established in vitro and with age of 80 days, length of $2 \pm 0.5 \mathrm{~cm}$ and obtained from germination of seeds, were used as explants. The plants were transferred to test tubes containing $5 \mathrm{ml}$ stationary liquid MS medium (Murashige and Skoog, 1962) supplemented with $30 \mathrm{~g} \mathrm{~L}^{-1}$ sucrose and BAP (Sigma-Aldrich, St. Louis, USA) at concentration of 0,5 , 10 or $15 \mu \mathrm{M}$. The experiment was conducted with one plant per test tube. The medium's $\mathrm{pH}$ was adjusted to 5.8 before autoclaving at $120^{\circ} \mathrm{C}$ for $20 \mathrm{~min}$. After inoculation in the laminar flow chamber, the plant material was kept in a growth room, for 60 days, at $25 \pm 2{ }^{\circ} \mathrm{C}$ and $16: 8 \mathrm{~h}$ light:dark photoperiod under fluorescent tube lamps (Empalux FT8 HO, 36W/6400K, Empalux, Paraná, Brazil), which provided $90 \mu \mathrm{mol} \mathrm{m}^{-2} \mathrm{~s}^{-1}$ of PAR.

To ascertain the multiplication rate, 60 plants with their shoot buds per treatment were collected at random and divided into six groups. The number of adventitious shoots per plant and the budding percentage were evaluated.

\section{In vitro rooting of previously multiplied plants}

In order to evaluate the residual effects of the BAP during in vitro rooting, a second experiment was conducted. After 
60 days in the medium with various BAP concentrations, the explants from each treatment were subcultivated into $268 \mathrm{ml}$ glass containers containing $50 \mathrm{ml}$ of the MS culture medium supplemented with $30 \mathrm{~g} \mathrm{~L}^{-1}$ sucrose and without any PGR. The subculture was performed in a stationary liquid medium for 60 days. This step was carried out with five buds per glass container.

At 60 days of subcultivation, the microshoots obtained from each previous BAP treatment, with approximate length of $3 \pm 1 \mathrm{~cm}$, were individualized with the aid of a scalpel. Then the adventitious shoots were transferred to $280 \mathrm{ml}$ glass containers containing $50 \mathrm{ml}$ of the MS culture medium supplemented with 30 $\mathrm{g} \mathrm{L}^{-1}$ sucrose, NAA (Sigma-Aldrich, St. Louis, USA) at concentration of 0,2 or $4 \mu \mathrm{M}$ and solidified with 6 $\mathrm{g} \mathrm{L}^{-1}$ agar (Vetec ${ }^{\circledR}$, Darmstadt, Germany). The second experiment was conducted with five shoots per glass container. The $\mathrm{pH}$ of all the media was adjusted to 5.8 before autoclaving at $120{ }^{\circ} \mathrm{C}$ for $20 \mathrm{~min}$. After sterile inoculation, the material was kept in a growth room under the conditions mentioned above. At 60 days of growth, 25 plants from each treatment were sampled randomly and divided into five parcels. The fresh weight of roots and aerial part ( $\mathrm{g}$ plant $\left.{ }^{-1}\right)$ were determined.

\section{Anatomical analysis of in vitro rooted plants}

Anatomical characterization of the roots and leaves was performed on five plants from each treatment (4 BAP X 3 NAA concentrations). Samples were randomly collected at 60 days of growth and fixed in formaldehyde, acetic acid, and ethanol (FAA; 50\%, 0.5/0.5/9, $\mathrm{v} \mathrm{v}^{-1}$ ) for $48 \mathrm{~h}$, followed by storage in $70 \%$ ethanol (Johansen, 1940). In the leaves, cross-sections were obtained in the median region of the first completely expanded leaf in the rosette central region with the aid of a double edge razor. Cross-sections were also taken at the root base $(0.5 \mathrm{~cm}$ from the shoot $)$. Sections were cleared using $10 \%\left(\mathrm{v} \mathrm{v}^{-1}\right)$ sodium hypochlorite, followed by staining with safranin and astra-blue solutions, and assembled on slides using 50\% $\left(\mathrm{V} \mathrm{v}^{-1}\right)$ glycerin. The sections were viewed using a light microscope (Bioval, L-2000A-Fluor combined with a Leica ICC50 HD camera; Leica, Wetzlar, Germany), and two cross-sections from each slide were photographed. The photomicrographs were used to measure the anatomical characteristics using the UTHSCSA-Imagetool ${ }^{\circledR}$ software calibrated with a microscopy ruler. For the roots, root diameter $(\mu \mathrm{m})$ and number of metaxylem vessels were measured. For the leaves, measurements were taken of the thickness of the hydrenchyma $(\mu \mathrm{m})$, chlorenchyma $(\mu \mathrm{m})$, hypodermis $(\mu \mathrm{m})$ as well as the number and diameter $(\mu \mathrm{m})$ of xylem vessels.

Extraction and analysis of photosynthetic pigments of in vitro rooted plants

The photosynthetic pigments were quantified in seven plants for each treatment, collected at random. The pigments were extracted from $0.04 \mathrm{~g}$ of fresh matter obtained from the third completely expanded leaf from the central rosette. The material was placed in test tubes containing $5 \mathrm{ml} \mathrm{80 \%}$ $\left(\mathrm{v} \mathrm{v}^{-1}\right)$ acetone and maintained for 72 hours in the dark at a constant temperature of $4{ }^{\circ} \mathrm{C}$. Then the absorbances were read with a spectrophotometer (Genesys ${ }^{\mathrm{TM}} 10 \mathrm{~S}$ UV-Vis/ Thermo Fisher Scientific) at $\lambda=470,645$ and $663 \mathrm{~nm}$ for carotenoids (Car), chlorophyll $b(\mathrm{Chl} b)$ and chlorophyll $a$ $(\mathrm{Chl} a)$ respectively. The readings were used to calculate the contents as proposed by Arnon (1949). The contents were expressed as micrograms of pigment per gram of fresh weight ( $\left.\mu \mathrm{g} \mathrm{g}^{-1} \mathrm{FW}\right)$.

\section{Statistical analysis}

The first experiment was performed with four different BAP concentrations $(0,5,10$, and $15 \mu \mathrm{M})$ using a completely randomized design. The second experiment was conducted in a completely randomized design in a factorial arrangement with four previous BAP treatments $(0,5,10$ or $15 \mu \mathrm{M})$ and three NAA concentrations $(0,2$ or $4 \mu \mathrm{M})$, for a total of 12 treatments. The resulting data were submitted to an analysis of variance (ANOVA), and the significance of differences between mean values was determined using the Tukey test at 5\% probability. Besides, to verify significant adjustments to trend models, the data were subjected to regression analysis. All statistical analyses were performed using the SISVAR ${ }^{\circledR}$ software.

\section{Results}

\section{In vitro multiplication}

All plants presented the formation of adventitious shoots, independent of BAP concentration used (100\% budding). However, the number of adventitious shoots per plant was influenced by the treatments. BAP supplementation showed a clear positive effect of increasing the number of adventitious shoots. Conversely, the number decreased at concentrations higher than $10 \mu \mathrm{M}$ BAP $\left(\mathrm{R}^{2}=0.95 ; \hat{\mathrm{y}}=\right.$ $\left.-0.1003 x^{2}+1.7212 x+3.5253\right)$ (Figure 1). 


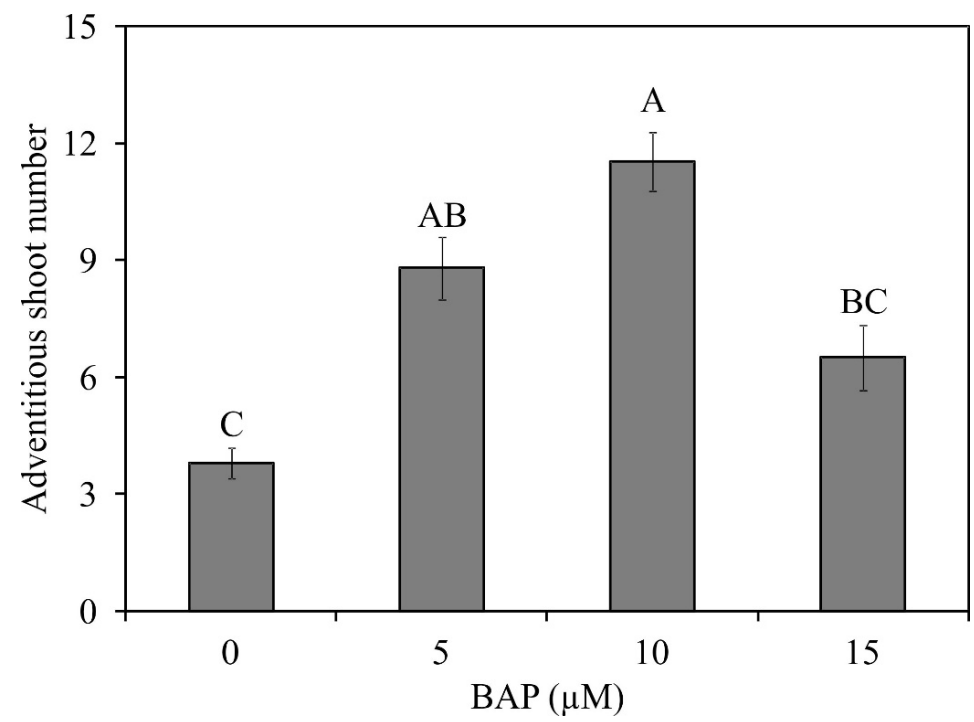

Figure 1. Number of adventitious shoots of Alcantarea imperialis plants during in vitro multiplication in function of 6-benzylaminopurine (BAP) concentrations $(\mu \mathrm{M})$. Means $( \pm$ SE) followed by the same letter are not significantly different according to the Tukey test at $5 \%$.

\section{In vitro rooting}

After 120 days of growth without direct BAP exposure, root formation was observed in all shoots (Figure 2). Nevertheless, the rooting responses were modulated by the NAA concentrations and the previous BAP treatments. The lowest fresh weights of roots were verified in shoots cultured in all treatments without exogenous AUX.
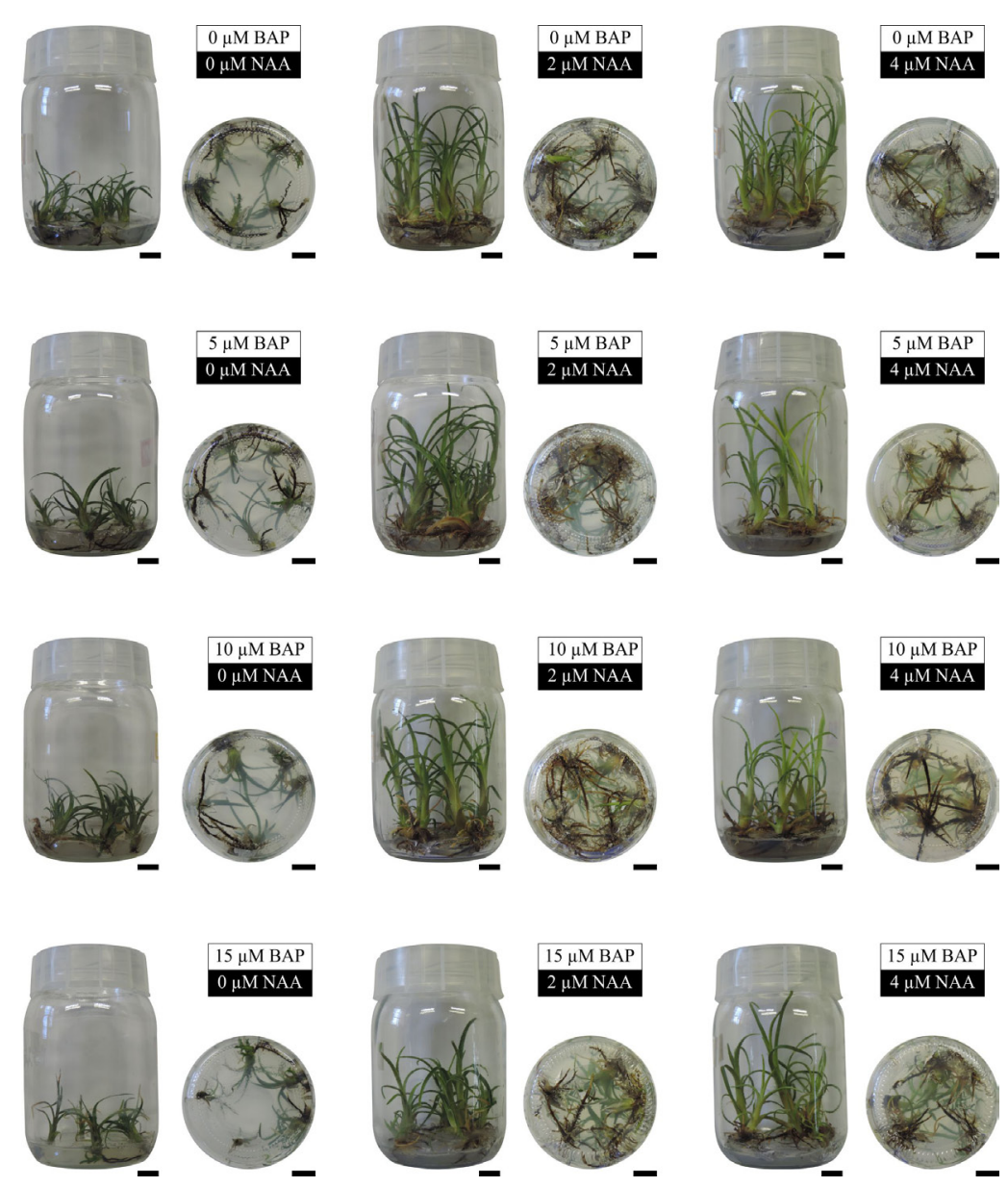

Figure 2. Visual aspects of Alcantarea imperialis plants grown in a medium with different 1-naphthaleneacetic acid (NAA) concentrations $(0,2$ or $4 \mu \mathrm{M})$ and previous 6-benzylaminopurine (BAP) treatments $(0,5,10$ or $15 \mu \mathrm{M})$. Bars $=1 \mathrm{~cm}$. 
Plants cultured with $2 \mu \mathrm{M}$ NAA supplementation presented a positive increase of the root fresh weight, but when the shoots were previously grown with BAP concentrations higher than $5 \mu \mathrm{M}$, a decrease of root fresh weight was observed. With $4 \mu \mathrm{M}$ NAA, the fresh weight was similar, irrespective of previous BAP treatments. The highest values were verified in shoots previously grown with 0 and $5 \mu \mathrm{M}$ BAP and then cultured with $2 \mu \mathrm{M}$ NAA (Figure 3 ).

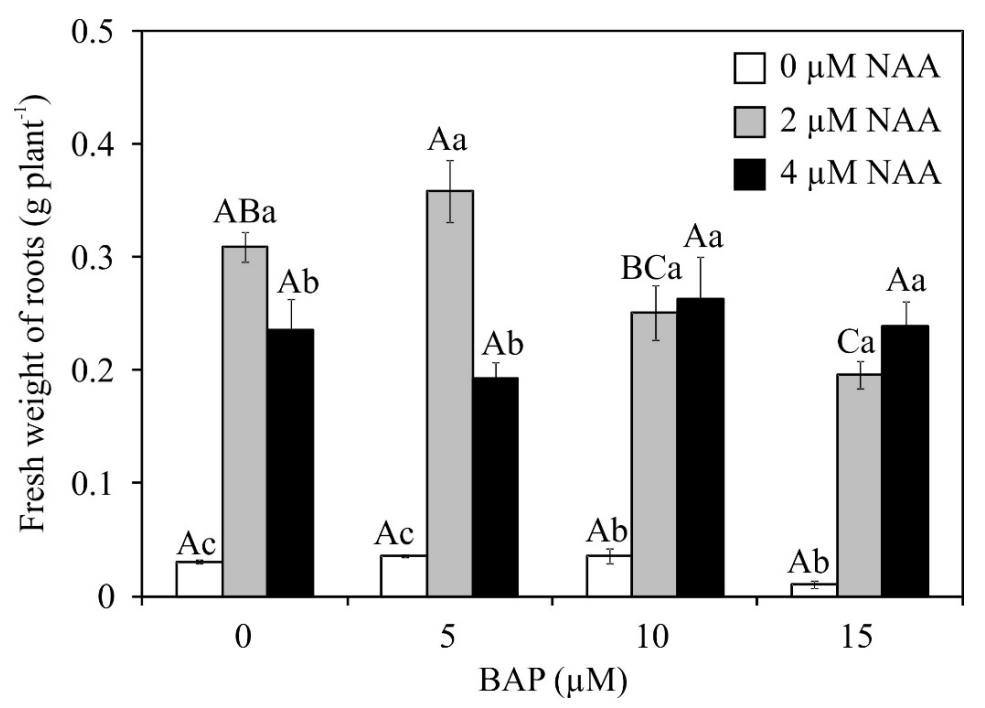

Figure 3. Fresh weight $\left(\mathrm{g}_{\text {plant }}{ }^{-1}\right)$ of roots of Alcantarea imperialis plants after in vitro rooting in function of 1-naphthaleneacetic acid (NAA) concentration $(0,2$ or $4 \mu \mathrm{M})$ and previous 6-benzylaminopurine (BAP) treatment $(0,5,10$ or $15 \mu \mathrm{M})$. Means $( \pm \mathrm{SE})$ followed by the same letter (uppercase for each NAA concentration - comparing the previous BAP exposure at each NAA concentration; and lowercase for each previous BAP exposure - comparing the NAA concentration after each previous BAP concentration) are not significantly different according to the Tukey test at 5\%.

In the aerial part of plants, visual morphological differences were verified. Plants cultured without NAA supplementation were smaller, while plants grown with $4 \mu \mathrm{M}$ NAA presented longer leaves with visible physiological disturbances such as leaf discoloration (Figure 2). With respect to growth trait of the aerial part, both previous BAP treatments and NAA concentrations influenced the growth, expressed as fresh weight accumulation. However, these variation factors (previous
BAP concentrations and NAA concentrations) did not present a significant interaction. When A. imperialis plants were grown without NAA, they presented the lowest biomass accumulation of aerial part. On the other hand, the highest fresh weight of aerial part occurred in plants cultured under $2 \mu \mathrm{M}$ NAA. A linear decrease of the fresh weight of aerial part $\left(R^{2}=0.87 ; \hat{y}=-0.013 x+\right.$ 0.711 ) was verified as a function of the previous treatments with BAP concentrations (Figure 4). 


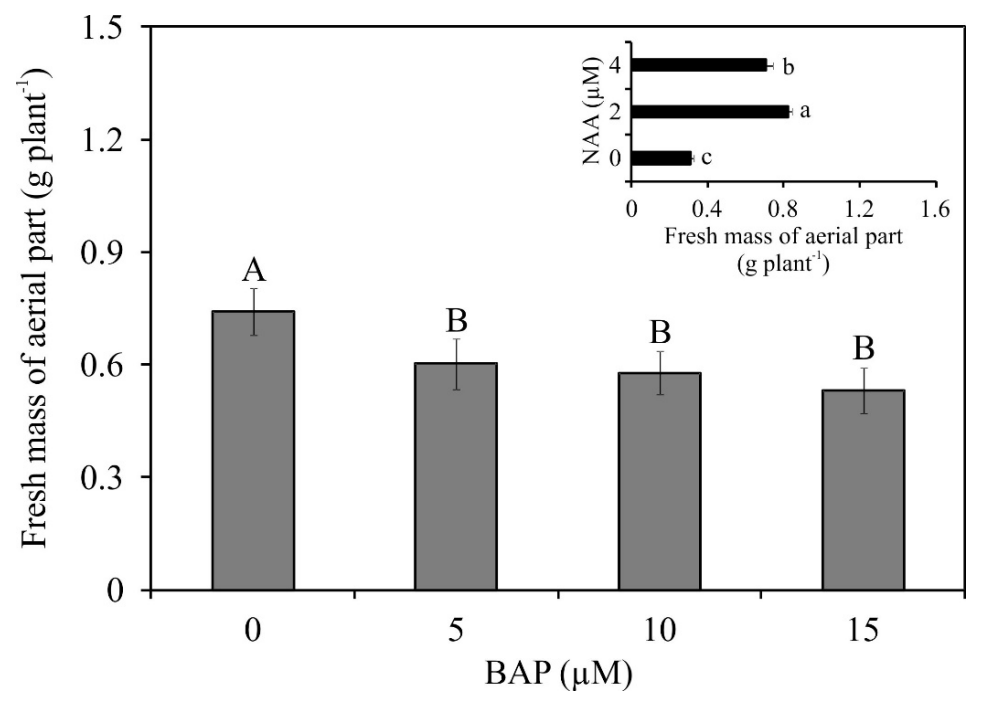

Figure 4. Fresh weight $\left(\mathrm{g}_{\text {plant }} \mathrm{t}^{-1}\right)$ of aerial part of Alcantarea imperialis plants after in vitro rooting in function of 1-naphthaleneacetic acid (NAA) concentration $(0,2$ or $4 \mu \mathrm{M})$ or previous 6-benzylaminopurine (BAP) treatment (0, $5,10$ or $15 \mu \mathrm{M})$. For each NAA concentration $(\mu \mathrm{M})$ or previous BAP concentration $(\mu \mathrm{M})$ employed, means $( \pm \mathrm{SE})$ followed by the same letter are not significantly different according to the Tukey test at $5 \%$.

Under in vitro conditions, the transversal root sections of A. imperialis plants presented a uniseriate epidermal layer with unicellular hairs, velamen with multiseriate cell layers, and an outer and inner cortex. Both inner and outer cortexes were parenchymatous, with multiseriate cell layers, but the outer cortex (also known as exodermis) presented thicker cell walls. The last cell layer of the cortex is known as the endodermis, which also presented thicker cell walls (Figure 5).

The treatments had an impact on modulation of root anatomy of $A$. imperialis. The proliferation of the cells was higher with $4 \mu \mathrm{M}$ NAA, which induced roots with the largest diameter when the shoots were previously grown with 0, 5 and $10 \mu \mathrm{M}$ BAP (Figure 5 and 6A). The exodermis was also influenced by these conditions. Adventitious shoots previously formed with 0,5 and 10 $\mu \mathrm{M}$ BAP and subsequently cultured in medium with $4 \mu \mathrm{M}$ NAA presented a thinner exodermis and many cell walls of this tissue did not show thickening (Figure 5). The roots grown in the others treatment conditions presented similar diameter (Figure 6A). 


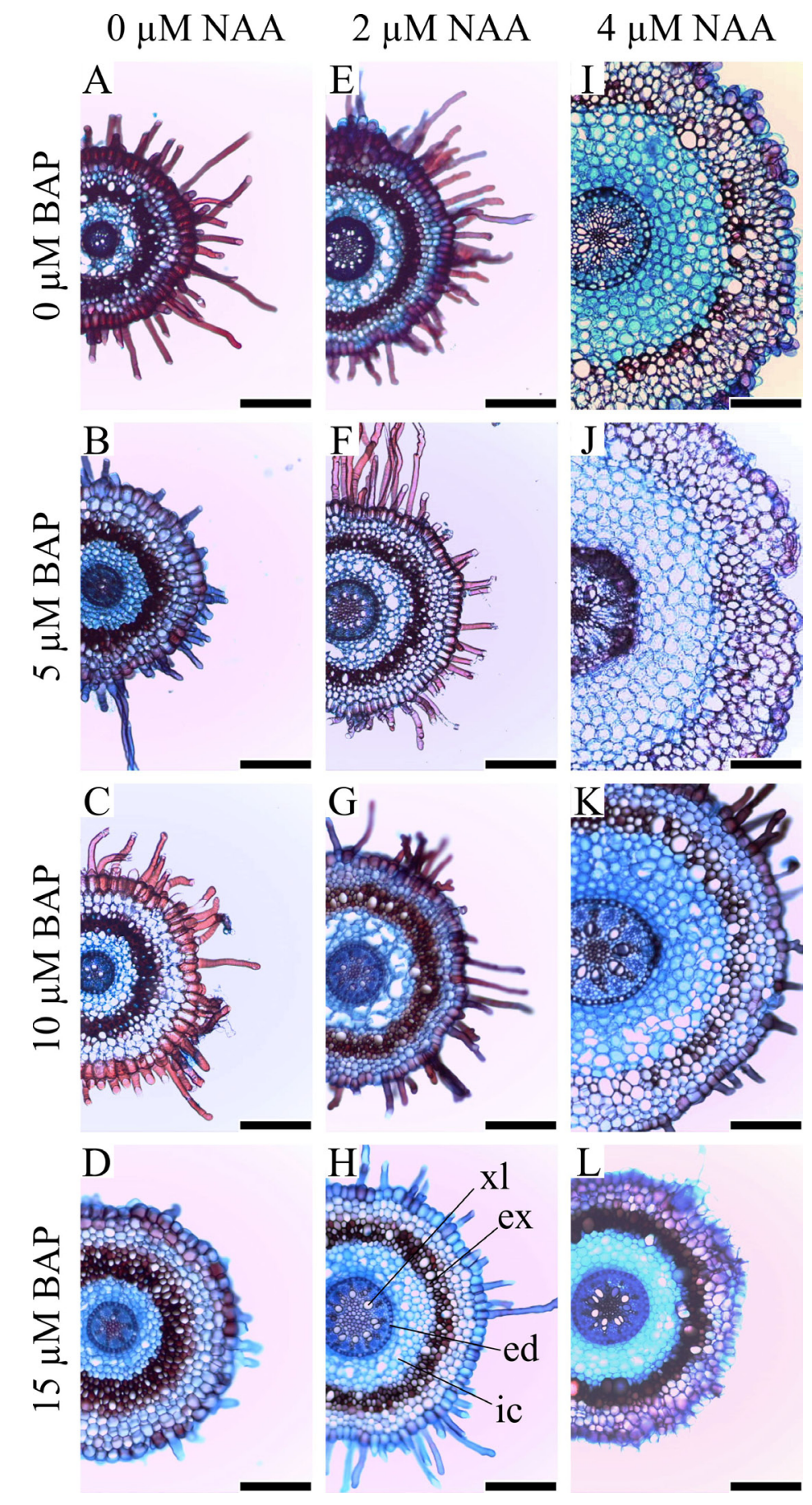

Figure 5. Root cross-sections of Alcantarea imperialis plants grown in medium with different concentrations of 1-naphthaleneacetic acid (NAA) $(0,2$ or $4 \mu \mathrm{M})$ and previous 6-benzylaminopurine (BAP) treatments $(0,5,10$ or 15 $\mu \mathrm{M})$. ic - inner cortex, ex - exodermis, ed - endodermis, and $\mathrm{xl}-\mathrm{xylem}$. Bars $=200 \mu \mathrm{m}$. 

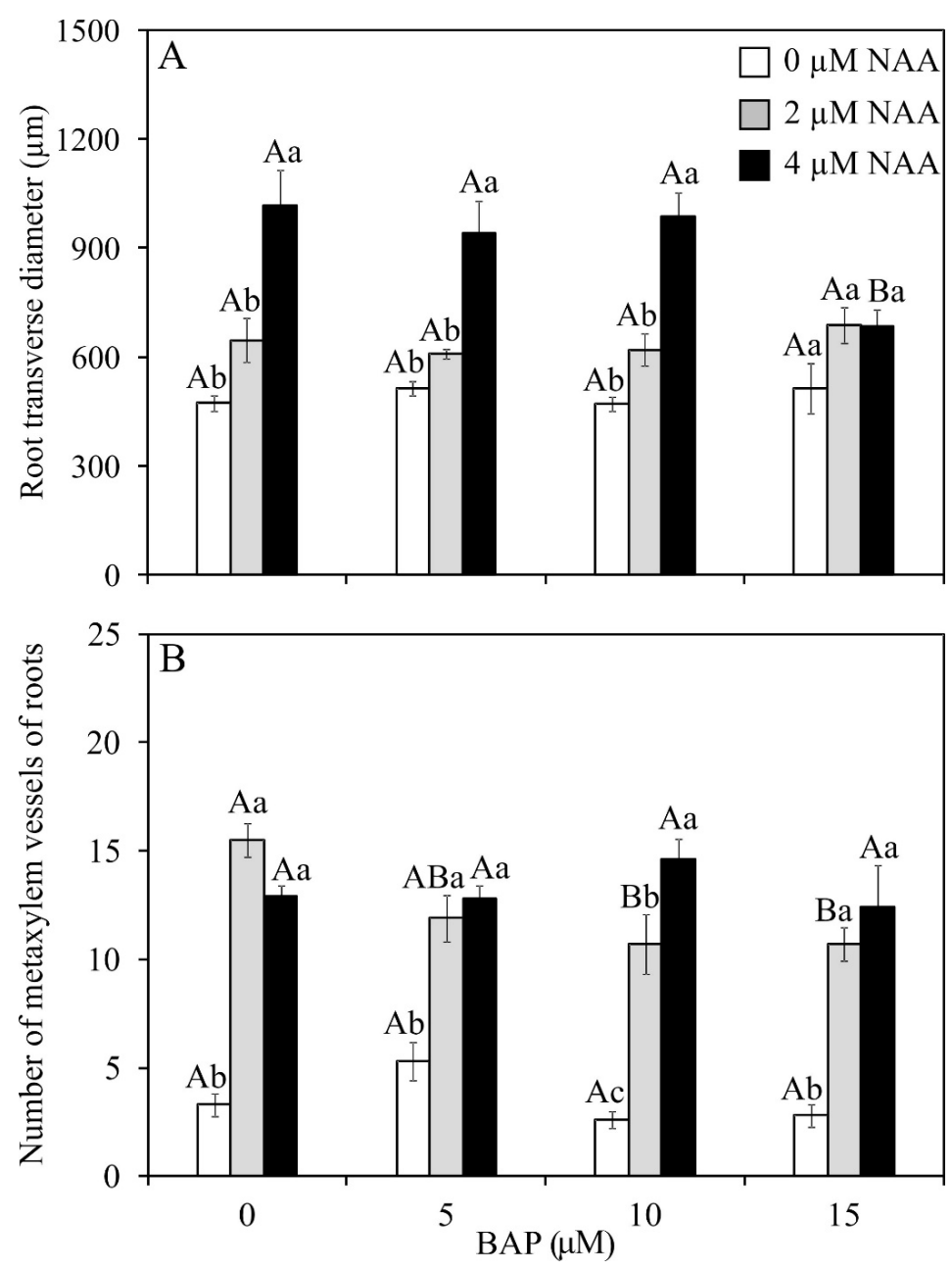

Figure 6. (A) Root transverse diameter $(\mu \mathrm{m})$ and $(\mathrm{B})$ number of metaxylem vessels of Alcantarea imperialis plants in function of 1-naphthaleneacetic acid (NAA) concentrations $(\mu \mathrm{M})$ and previous 6-benzylaminopurine (BAP) treatments $(\mu \mathrm{M})$. Means $( \pm \mathrm{SE})$ followed by the same letter (uppercase for each NAA concentration - comparing the previous BAP exposure at each NAA concentration; and lowercase for each previous BAP exposure - comparing the NAA concentration after each previous BAP concentration) are not significantly different according to the Tukey test at 5\%.

In addition, these plants' roots had exodermis with thickened cell walls as well as regular circular shape (Figure 5).

The number of metaxylem vessels of roots was also influenced by both variation factors. The NAAsupplementation increased the number of metaxylem vessels. With $2 \mu \mathrm{M}$ NAA, shoots previously formed with 0 and $5 \mu \mathrm{M}$ BAP issued roots that presented a higher number of vessels in relation to those cultured with 10 and $15 \mu \mathrm{M}$ BAP. Roots grown in medium supplemented with $4 \mu \mathrm{M}$ NAA presented a similar number of metaxylem vessels, independently of the previous BAP treatments. When analyzing the number of vessels in each previous BAP treatments, roots cultured without NAA had the lowest number of metaxylem vessels (Figure 6B).

The leaf anatomical traits of $A$. imperialis plants also showed differences in function of the treatments.
Adventitious shoots formed in medium supplemented with $\operatorname{BAP}(5,10$ and $15 \mu \mathrm{M})$ and then cultured with $4 \mu \mathrm{M}$ NAA in general presented the thickest hydrenchyma and chlorenchyma. In the shoots grown previously without BAP, the hydrenchyma presented similar thickness, irrespective of NAA treatments. The hydrenchyma presented a linear decrease $\left(\mathrm{R}^{2}=0.86 ; \hat{\mathrm{y}}=-5.332 \mathrm{x}+\right.$ 322.6) and linear increase $\left(R^{2}=0.80 ; \hat{y}=4.127 x+\right.$ 320.3) in function of previous BAP treatments with 0 and $4 \mu \mathrm{M}$ NAA, respectively. The chlorenchyma also presented a linear decrease $\left(\mathrm{R}^{2}=0.92 ; \hat{\mathrm{y}}=-1.558 \mathrm{x}+\right.$ 106.6) in function of previous BAP treatments with 0 $\mu \mathrm{M}$ NAA. The thickest chlorenchymas were found in adventitious shoots previously cultured without BAP and then with $2 \mu \mathrm{M}$ NAA (Figure 7 and Table 1 ). 

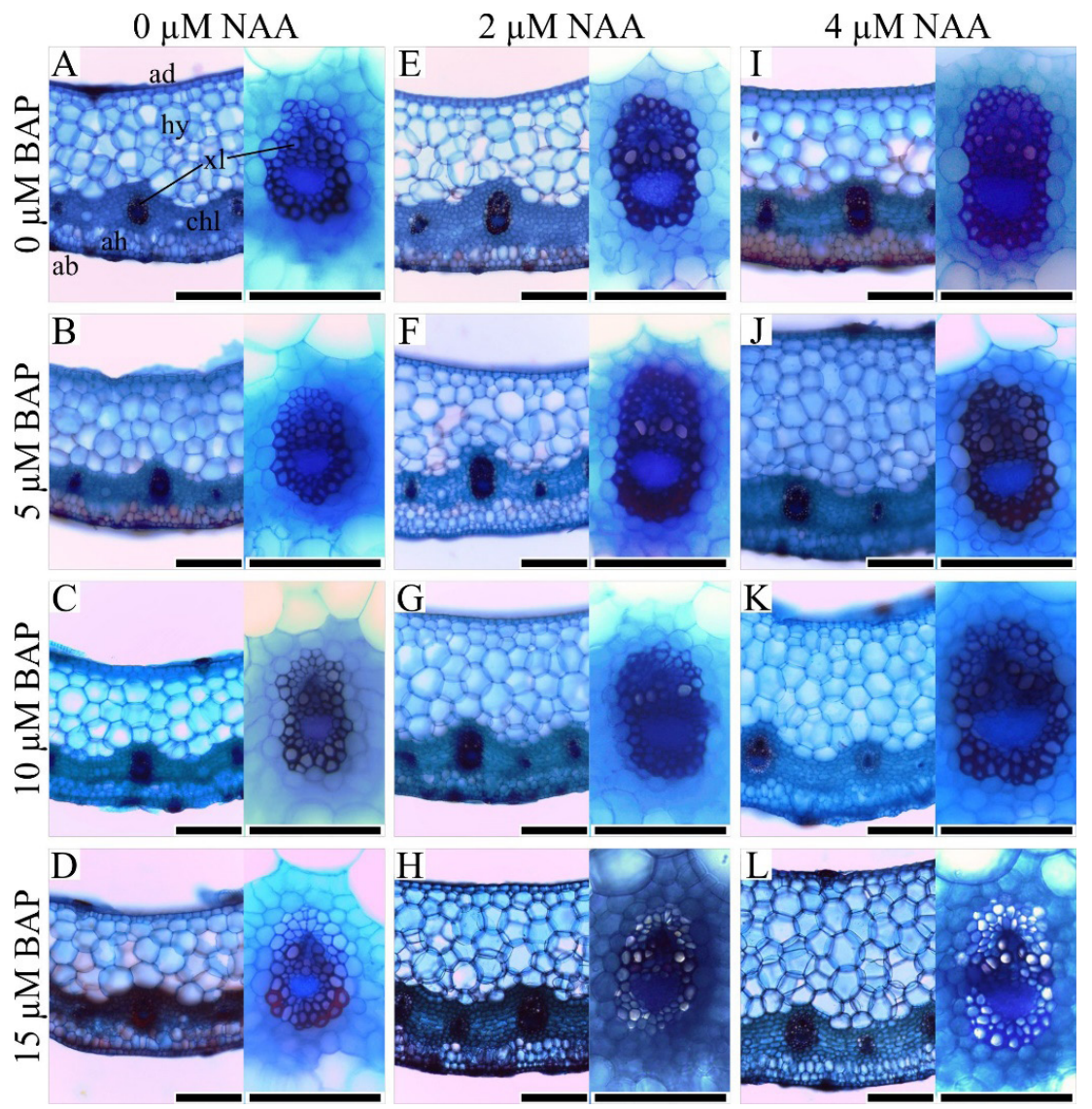

Figure 7. Cross-sections of leaves of Alcantarea imperialis plants grown in medium with different concentrations of 1-naphthaleneacetic acid (NAA) $(0,2$ or $4 \mu \mathrm{M})$ and previous 6-benzylaminopurine (BAP) treatments $(0,5,10$ or $15 \mu \mathrm{M})$. ad - adaxial epidermis, ab - abaxial epidermis, ah - aquifer hypodermis, hy hydrenchyma, chl - chlorenchyma, and $\mathrm{xl}-\mathrm{xylem}$. Bars $=200 \mu \mathrm{m}$.

Table 1. Anatomical structures of leaves of Alcantarea imperialis plants after in vitro rooting in function of 1-naphthaleneacetic acid (NAA) concentrations $(\mu \mathrm{M})$ and previous 6-benzylaminopurine (BAP) treatments $(\mu \mathrm{M})$.

\begin{tabular}{|c|c|c|c|c|c|c|c|c|c|}
\hline \multirow{3}{*}{$\begin{array}{l}\text { BAP } \\
(\mu \mathrm{M})\end{array}$} & \multicolumn{3}{|c|}{ hydrenchyma $(\mu \mathrm{m})$} & \multicolumn{3}{|c|}{ chlorenchyma ( $\mu \mathrm{m})$} & \multicolumn{3}{|c|}{ number of xylem vessels } \\
\hline & \multicolumn{9}{|c|}{$\mathbf{N A A}(\boldsymbol{\mu M})$} \\
\hline & $\mathbf{0}$ & 2 & 4 & $\mathbf{0}$ & 2 & 4 & $\mathbf{0}$ & 2 & 4 \\
\hline 0 & $314 \pm 13^{\mathrm{aA}}$ & $352 \pm 13^{\mathrm{aA}_{\mathrm{A}}}$ & $308 \pm 17^{\mathrm{bA}}$ & $109 \pm 3^{\mathrm{aC}}$ & $148 \pm 9^{\mathrm{aA}}$ & $129 \pm 4^{\mathrm{aB}}$ & $3.2 \pm 0.2^{\mathrm{aB}}$ & $4.5 \pm 0.3^{\mathrm{aA}}$ & $4.0 \pm 0.2^{\mathrm{bA}}$ \\
\hline 5 & $300 \pm 18^{\mathrm{aB}}$ & $298 \pm 11^{\mathrm{aB}}$ & $360 \pm 25^{\mathrm{abA}}$ & $95 \pm 2^{\mathrm{abB}}$ & $108 \pm 1^{\mathrm{bB}}$ & $127 \pm 2^{\mathrm{aA}}$ & $3.5 \pm 0.2^{\mathrm{aB}}$ & $4.8 \pm 0.1^{\mathrm{aA}}$ & $4.7 \pm 0.1^{\mathrm{abA}}$ \\
\hline 10 & $286 \pm 13^{\mathrm{abB}}$ & $319 \pm 8^{\mathrm{aAB}}$ & $360 \pm 10^{\mathrm{abA}}$ & $89 \pm 2^{\text {bB }}$ & $115 \pm 3^{\mathrm{bA}}$ & $123 \pm 6^{\mathrm{aA}}$ & $3.0 \pm 0.2^{\mathrm{aB}}$ & $4.9 \pm 0.2^{\mathrm{aA}}$ & $5.4 \pm 0.1^{\mathrm{aA}}$ \\
\hline 15 & $230 \pm 6^{\mathrm{bC}}$ & $316 \pm 14^{\mathrm{aB}}$ & $377 \pm 29^{\mathrm{aA}}$ & $85 \pm 2^{\mathrm{bC}}$ & $110 \pm 2^{\mathrm{bB}}$ & $127 \pm 5^{\mathrm{aA}}$ & $3.7 \pm 0.1^{\mathrm{aA}}$ & $4.4 \pm 0.3^{\mathrm{aA}}$ & $4.4 \pm 0.2^{\mathrm{bA}}$ \\
\hline
\end{tabular}

Means ( \pm SE) followed by the same letter, lowercase in the column and uppercase in the row, are not significantly different according to the Tukey test at $5 \%$.

The aquifer hypodermis did not change as a function of treatments and showed thickness of $64 \mu \mathrm{m} \pm 3.2$. On the other hand, the number and diameter of xylem vessels were influenced by the treatments.

In general, adventitious shoots grown without NAA had leaves with lower number and diameter of vessels.
In contrast, the supplementation of NAA $(2$ and $4 \mu \mathrm{M})$ induced leaves with higher number and diameter of xylem vessels (Table 1 and Figures 7 and 8). Plants cultured previously with $15 \mu \mathrm{M}$ BAP produced leaves with thinner (smaller diameter) xylem vessels, independent of NAA concentration applied (Figures 7 and 8). 


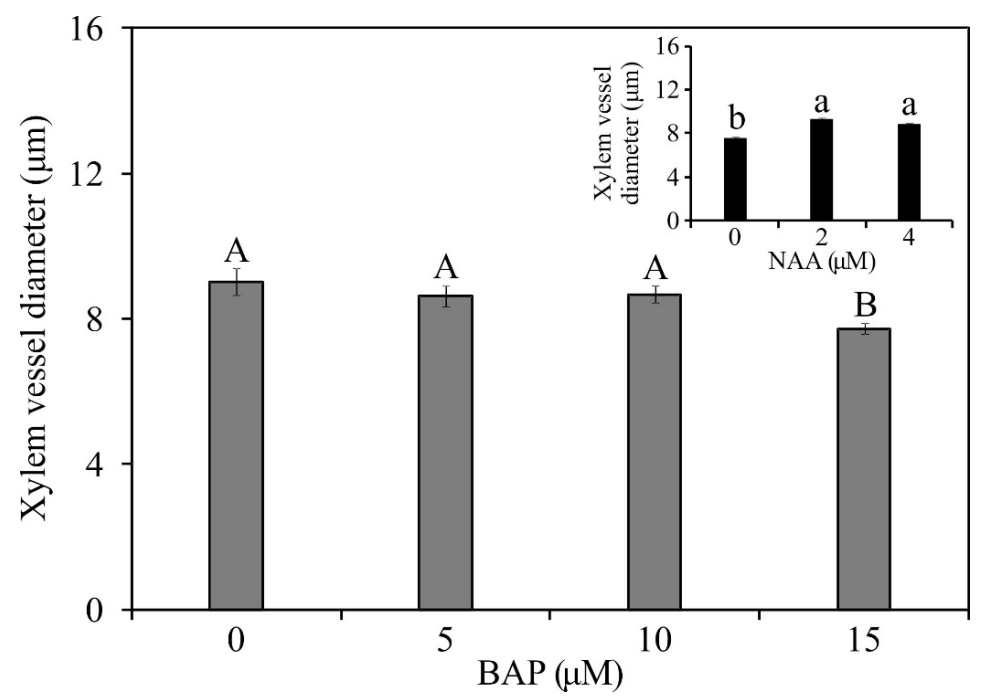

Figure 8. Xylem vessel diameter of leaves of Alcantarea imperialis plants after in vitro rooting in function of 1-naphthaleneacetic acid (NAA) concentration $(0,2$ or $4 \mu \mathrm{M})$ or previous 6-benzylaminopurine (BAP) treatment $(0$, $5,10$ or $15 \mu \mathrm{M})$. For each NAA concentration $(\mu \mathrm{M})$ or previous BAP concentration $(\mu \mathrm{M})$ employed, means $( \pm \mathrm{SE})$ followed by the same letter are not significantly different according to the Tukey test at $5 \%$.

The photosynthetic pigment contents of $A$. imperialis plants showed differences in function of the treatments. However, the variation factors did not present a significant interaction. Plants cultured in media with $2 \mu \mathrm{M}$ NAA added had higher photosynthetic pigment contents (Chl total, Chl $a, \mathrm{Chl} b$ and Car), irrespective of previous BAP treatments.
On the other hand, plants grown with $4 \mu \mathrm{M}$ NAA presented the lowest contents of all pigments as well as $\mathrm{Chl} a / b$ ratio (3.75). Adventitious shoots formed earlier without BAP presented the highest content of Chl total, $\mathrm{Chl} a, \mathrm{Chl} b, \mathrm{Car}$, and $\mathrm{Chl} a / b$ ratio during the in vitro rooting, independent of NAA concentrations (Figure 9).

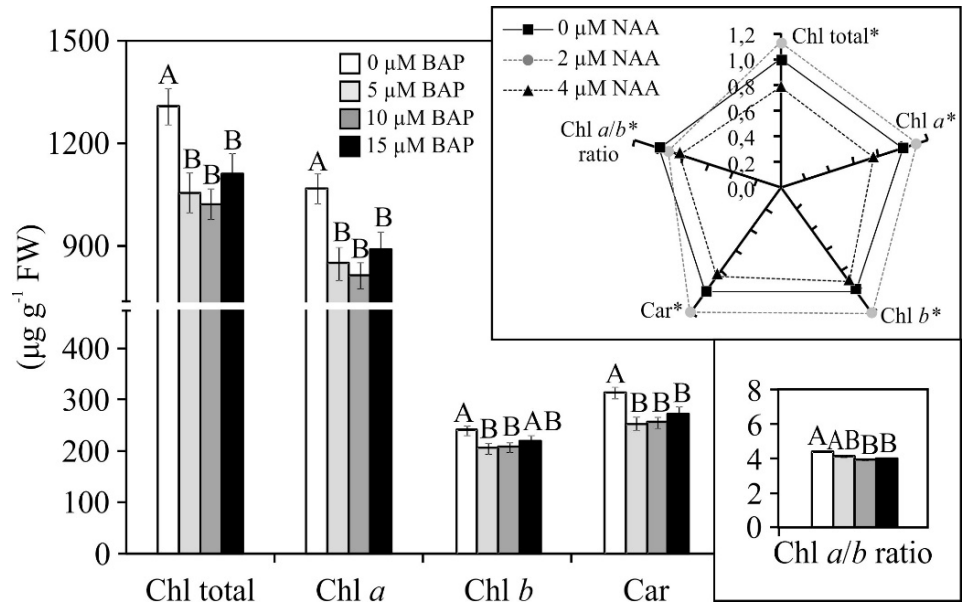

Figure 9. Photosynthetic pigment contents $\left(\mu \mathrm{g} \mathrm{g}^{-1} \mathrm{FW}\right)$ of Alcantarea imperialis plants after in vitro rooting in function of 1-naphthaleneacetic acid (NAA) concentration $(0,2$ or $4 \mu \mathrm{M})$ or previous 6-benzylaminopurine (BAP) treatment $(0,5,10$ or $15 \mu \mathrm{M})$. For each previous BAP concentration $(\mu \mathrm{M})$ employed, means $( \pm \mathrm{SE})$ followed by the same letter, for each photosynthetic pigment content, are not significantly different according to the Tukey test at 5\%. For each photosynthetic pigment content analyzed, means followed by asterisk are significantly different according to the Tukey test at $5 \%$. The pigment traits in function of NAA concentration $(\mu \mathrm{M})$ were normalized relative to $0 \mu \mathrm{M}$. 


\section{Discussion}

For in vitro culture of bromeliads, normally exogenous CK supplementation is necessary to induce adventitious shoots at the plants' base (Viehmannova et al., 2016; Rosa et al., 2018). However, the exposure to exogenous CKs was not a limiting factor for inducing adventitious shoots in A. imperialis. Side shoot formation without supplementation of PGRs in culture media has already been reported in species of the subfamily Tillandsioideae (Resende et al., 2016; Martins et al., 2020). Bromeliads can produce adventitious shoots under abiotic stress during in vitro growth (Martins et al., 2020). In fact, the process of adventitious shoot formation of bromeliads grown in vitro is correlated to physiological responses to stress (Rosa et al., 2018). Exogenous stress factors can activate genes that alter the endogenous hormonal balance of CKs (Macková et al., 2013), which can promote the development of adventitious shoots. The induction of side shoots could also be related to ethylene, produced by the plants and accumulated inside containers. The internal atmosphere of conventional in vitro containers is a potential accumulator of ethylene (Ozudogru et al., 2017), which can affect plant regeneration and inducing side shoots in bromeliads (Van Dijck et al., 1988). Furthermore, these conventional in vitro environmental conditions may have induced some alterations of hormonal balance of $A$. imperialis, leading to formation of adventitious shoots in plants cultured in medium with free exogenous CK. Nevertheless, in our study, we verified a considerable increment of adventitious shoots with BAP supplementation. The reason for the increase in the number of shoots is because CKs promote the growth of axillary shoots and end apical dominance (Singh et al., 2016). On the other hand, with high CK concentrations, plants may face a higher level of stress, which can activate genes related to synthesis of cytokinin oxidases/dehydrogenases, which in turn bind to specific sites of the substrate, causing CK catalysis (Kopečný et al., 2016). The decrease of adventitious shoots with 15 $\mu \mathrm{M}$ BAP could be related to the cleaving activity of these enzyme systems. This enzymatic action can reduce or inhibit the action of exogenous CKs in breaking the apical dominance, impeding the formation of new shoots (Rosa et al., 2018).

Besides the effects of BAP during in vitro multiplication, this exogenous $\mathrm{CK}$ also presented clear residual effects on plants over a long period. Changes of anatomy, physiology and growth traits of $A$. imperialis were observed in plants even after 120 days without direct BAP exposure. After in vitro plants have been treated with exogenous $\mathrm{CK}$, they may show a reduced rooting response (Martins et al., 2018b). This is because CKs are plant hormones that influence a wide range of developmental processes, including inhibition of rooting at higher concentrations (Bekircan et al., 2018). In our work, A. imperialis shoots did not require exogenous AUX to ensure the rooting response. This can be attributed to the fact that endogenous AUX ensures the in vitro rooting of some plant species (Martins et al., 2018a). The generation of adventitious roots is dependent on endogenous AUX level, which plays an essential role in the reprogramming process of cell fate (Sang et al., 2016). However, NAA increased the root fresh weight (higher number of roots) during in vitro rooting of $A$. imperialis. Satisfactory rates of induction of adventitious roots of bromeliads from in vitro shoots are usually promoted by AUX supplementation in the culture medium (Martins et al., 2018a). The ratio of endogenous AUX to CK concentrations plays as an important key for adventitious root formation (Bernula et al., 2020). This study demonstrates that alterations in hormone homeostasis induced by earlier exposure to BAP and then direct exposure to NAA can significantly change the rooting response. We suggest that high BAP concentrations applied during the in vitro multiplication may need exogenous AUXs to compensate the hormone balance and ensure the induction of a larger root system, since CK can inhibit the early stages of adventitious root primordium initiation and formation via the suppression of AUX synthesis and transport related genes (Mao et al., 2019).

The anatomy of $A$. imperialis is in accordance with the previous description of this species (Martins et al., 2020). The changes observed in the root anatomy of $A$. imperialis plants in function of the treatments can alter the transport of water and mineral compounds from the medium. The employment of AUX had a positive impact on number of metaxylem vessels of roots. This is because AUX plays a vital role in controlling plant growth and development via promotion of cell division (proliferation), growth (expansion, elongation) and differentiation (Majda and Robert, 2018). An increased number metaxylem vessels promoted by exogenous AUX can improve the translocation of water, sucrose, and all nutrients (Martins et al., 2018a). Therefore, higher translocation of nutrients and water from the medium can increase plant biomass, including the formation of new roots.

Plants previously grown with 0,5 and $10 \mu \mathrm{M}$ BAP and then $4 \mu \mathrm{M}$ NAA presented anatomical disorders in the roots. Under these in vitro conditions, alterations of root transverse diameter as well as thickness of exodermis were related to higher cell division induced by a hormonal imbalance. Higher AUX levels can increase meristem size and promote cell division in the proximal meristem of roots (Mambro et al., 2017). In addition, AUXs participate in the regulation of cell wall properties by inducing wall loosening (Majda and Robert, 2018). On the other hand, a CK application reduces the size of meristems and promotes cell differentiation in the roots' transition zone (Dello-Ioio et al., 2007). In our work, shoots previously cultured with $15 \mu \mathrm{M}$ BAP and then $4 \mu \mathrm{M}$ NAA had similar morphology as those from the other treatments $(0$ or $2 \mu \mathrm{M}$ NAA combined with any previous BAP concentration). Thus, we suggest that under these in vitro conditions, at least partial hormonal balance was re-established.

In the regular root development of bromeliads, the exodermis tissue is characterized by secondary cell walls, forming an apoplastic barrier around of inner cortex. The process of lignification and suberization of cell walls of the exodermis occurs naturally in bromeliads and has already 
been reported in in vitro-cultured bromeliads (Martins et al., 2018b; Martins et al., 2020). The cells with lignified and suberized walls of the exodermis also assume an import role, in conjunction with the velamen, offering mechanical protection and preventing water from returning from the cortex to the external environment, a fundamental strategy of plants with those tissues (Joca et al., 2017). The exodermis works as a barrier to apoplastic flow, thereby regulating the movement of water and mineral elements between the cell layers (Martins et al., 2020). In a recently published work, Martins et al. (2018a) reported that cell walls of the exodermis were thinner with rising NAA concentrations, but the tissue still presented regular shape, with secondary walls in all cells around the inner cortex. However, during in vitro culture of $A$. imperialis, the direct exposure to $4 \mu \mathrm{M}$ NAA combined with low endogenous CK (treatments with low previous BAP concentrations) may induce alteration in the formation of secondary cells due to modifications of the ratio of endogenous AUX to $\mathrm{CK}$, which can result in anatomical disorders of roots. According to Mamedes-Rodrigues et al. (2019), CKs like BAP seem to be involved in the accumulation of lignin of in vitro plants, since it positively regulates some genes related to secondary cell wall biosynthesis.

A functional root system during the in vitro culture of bromeliads is essential for an improved growth rate, and is reflected in higher bioaccumulation of the aerial part (Martins et al., 2018a). This can explain why plants cultured without NAA supplementation had the lowest growth trait values. The increase of plant growth with $2 \mu \mathrm{M}$ NAA was associated with the formation of roots with enhanced functionality. In contrast, the effect of previous BAP exposure last over a long period of in vitro propagation, mainly regarding root system formation (Martins et al., 2018b), which can directly affect the growth of the entire plant.

Changes in the anatomical traits of leaves of $A$. imperialis plants were linked to $\mathrm{CK}$ and NAA synergy. Plants cultured without NAA presented clear residual effects of previous BAP treatments. In our study, even though we did not measure cell size, the reduction in the hydrenchyma and chlorenchyma thickness seemed to be due to the lower number of cell layers, related to a lower cell division rate. This lower cell division rate also interfered with growth of those plants, since they had shorter leaves (Figure 2). High endogenous CK can modify the whole morphogenesis of plants, including reduction of root and stem growth as well as reduced leaf expansion (Martins et al., 2018b). Leaf growth is controlled by close coordination of cell division and cell expansion. AUXs promote cell division and expansion and can be transported actively through vascular bundles (Bennett et al., 2016). In monocots, the AUX concentration may have an impact on leaf elongation, since leaf bases contain the highest auxin content, which contributes to the high rates of cell division and elongation of leaf bases (Avramova et al., 2015). Therefore, NAA may have been transported from the culture medium to the aerial parts by vascular bundles at the base of the explant cut, thereby contributing to the increased growth and inducing thicker leaf tissues in A. imperialis.
Still regarding leaf anatomy, the diameter and number of xylem vessels are normally used to calculate the theoretical hydraulic conductivity based on the HagenPoiseuille equation (Jupa et al., 2015). Thus, the variation in these anatomical traits strongly affects axial water conductance. Improved hydraulic conductivity can result in water accumulation in the vacuoles, which induces high turgor pressure, driving the growth of newly formed cells (Majda and Robert, 2018). In our study, the NAA supplementation promoted an increment in the number and diameter of xylem vessels. In contrast, plants previously cultured with $15 \mu \mathrm{M}$ BAP presented smaller diameter of leaf xylem vessels. The increment in the number and diameter of xylem vessels (leaves as well as roots) induced by NAA in $A$. imperialis probably allowed an increase of the mineral and water conductivity from the medium to aerial part, resulting in greater growth of plants.

Residual effects of previous BAP treatments were also clear in the photosynthetic pigment contents. Similar results have been verified in the bromeliad A. blanchetiana (Martins et al., 2018b). The chlorophyll (Chl) content is usually correlated to photosynthetic apparatus efficiency of in vitro plants(Martins etal., 2016; Martins etal.,2020). Apronounced decrease in Chl content may correspond to pronounced impairment of photosystem II (PSII) function (Janečková et al., 2019). In fact, lower Chl content induced by previous BAP exposure can reduce the photosynthetic performance during in vitro culture of plants (Martins et al., 2018b). High endogenous CK content can cause hyperaccumulation of phenolic compounds and increase the activity of some enzymes of the antioxidant system (Mamedes-Rodrigues et al., 2019). Plants with high antioxidant system activity may present low photosynthetic pigment content due to the action of reactive oxygen species (ROS) (Gentile et al., 2017; Rodrigues et al., 2017). Likewise, high concentrations of exogenous AUX supplemented in the culture medium can increase the antioxidant system's activity (peroxidase) (Larraburu et al., 2016). Under oxidative stress, plants also grow slowly (Rodrigues et al., 2017).

Carotenoids (Car) have several functions in the metabolism processes of plants, such as photosynthesis and oxidative stress defense. Under oxidative stress, Car act as direct scavenging ROS, thus contributing cellular protection against membrane degradation and ROS mediated Chl degradation (Mostofa et al., 2017). Our results indicate that previous BAP treatments as well as NAA in concentrations higher than the ideal can reduce Car content, and this might contribute to $\mathrm{Chl}$ degradation, which may lead to a reduced efficiency of the photosynthetic apparatus.

The hormonal imbalance induced by previous BAP treatments and direct exposure to NAA changed the Chl $a / b$ balance. The $\mathrm{Chl}$ content is regulated by the balance between Chl biosynthesis and degradation. Thus, the synthesis and degradation activities should be examined to evaluate the controls of $\mathrm{Chl}$ accumulation (Sato et al., 2015). Chl synthesis is based in the Chl cycle, in which the Chl $a$ and Chl $b$ are interconverted by enzyme activities to regulate the $\mathrm{Chl} a / b$ ratio (Lim et al., 2019). The low $\mathrm{Chl} a / b$ ratio observed in plants cultured in previous 
BAP treatments or under $4 \mu \mathrm{M}$ NAA indicates that the proportion of Chl $b$ was higher than that of Chl $a$. Since Chl $b$ occurs mainly in light-harvesting complexes of PSII (LHCII), the decrease in the $\mathrm{Chl} a / b$ ratio reflects a relative decrease in reaction centers (RC) of PSII abundance (Leong and Anderson, 1984). Therefore, a decrease in the Chl $a / b$ ratio can indicate that the RCs of PSII are damaged to a greater extent than LHCII (Janečková et al., 2019). We suggest that this imbalance of $\mathrm{Chl} a / b$ could be related to the level of leaf senescence induced by the hormonal imbalance. During leaf senescence, $\mathrm{Chl}$ degradation occurs due to accumulation of ROS, increasing electrolyte leakage (Janečková et al., 2019). A reduction in $\mathrm{Chl} a / b$ ratio as a signal of leaf senescence has been reported (Janečková et al., 2019; Yang et al., 2019). This may explain why the plants cultured with $4 \mu \mathrm{M}$ NAA presented leaf discoloration (chlorosis).

\section{Conclusions}

In conclusion, during in vitro propagation of $A$. imperialis, the synergy of both previous BAP treatments and direct NAA exposure can change the physiology and anatomy of plants. The employment of BAP during the in vitro multiplication can increase the number of adventitious shoots per plant, but can induce negative effects over a long period on physiological status as well as change the anatomy of $A$. imperialis (120 days without BAP direct exposure). The supplementation with NAA in the culture medium can partially reverse the negative effects induced by the previous BAP exposure. Under the conditions set out, the application of $2 \mu \mathrm{M}$ NAA during in vitro rooting improved the quality of $A$. imperialis plants. Nevertheless, with $4 \mu \mathrm{M}$ NAA, the plants presented anatomical and physiological disorders. The results of the present study demonstrate that the rational application of CKs and AUXs is essential to improve the anatomical and physiological status of micropropagated plants.

\section{Author Contribution}

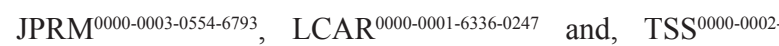
5480-4958 conducted experiments. JPRM and LCAR wrote the manuscript and carried out the statistical analysis. ARF ${ }^{0000-0002-}$ 0488-7441 and ABPLG ${ }^{0000-0003-3422-4398}$ provided the structure and conditions to develop the experiments and contributed to the discussion of results. All the authors read and approved the final version of the paper.

\section{Acknowledgements}

The authors would like to acknowledge the scholarship awarded by CAPES (Coordination for the Improvement of Higher Education Personnel), CNPq (Brazilian National Council for Scientific and Technological Development) and the FAPES (Espírito Santo State Research Foundation).

\section{References}

ARNON, D.I. Copper enzymes in isolated chloroplasts. Polyphenoloxidase in Beta vulgaris. Plant Physiology, v.24, n.1, p.1-15, 1949. DOI: https://doi.org/10.1104/ pp.24.1.1

AVRAMOVA, V.; SPRANGERS, K.; BEEMSTER, G.T.S. The maize leaf: another perspective on growth regulation. Trends in Plant Science, v.20, n.12, p.787-797, 2015. DOI: https://doi.org/10.1016/j.tplants.2015.09.002

BEKIRCAN, T.; YAŞAR, A.; YILDIRIM, S.; SÖKMEN, M.; SÖKMEN, A. Efect of cytokinins on in vitro multiplication, volatiles composition and rosmarinic acid content of Thymus leucotrichus Hal. shoots. 3 Biotech, v.8, p.180, 2018. DOI: https://doi.org/ 10.1007/s13205-0181206-2

BENNETT, T.; HINES, G.; VAN RONGEN, M.; WALDIE, T.; SAWCHUK, M.G.; SCARPELLA, E.; LJUNG, K.; LEYSER, O. Connective auxin transport in the shoot facilitates communication between shoot apices. PLoS Biology, v.14, n.4, p.e1002446, 2016. DOI: https://doi. org/10.1371/journal.pbio. 1002446

BERNULA, D.; BENKÖ, P.; KASZLER, N.; DOMONKOS, I.; VALKAI, I.; SZÖLLÖSI, R.; FERENC, G.; AYAYDIN F.; FEHÉR, A.; GÉMES, K. Timely removal of exogenous cytokinin and the prevention of auxin transport from the shoot to the root affect the regeneration potential of Arabidopsis roots. Plant Cell, Tissue and Organ Culture, v.140, n.2, p.327-339, 2020. DOI: https://doi.org/10.1007/s11240-019-01730-3

BROUWER, B.; ZIOLKOWSKA, A.; BAGARD, M.; KEECH, O.; GARDESTRÖM, P. The impact of light intensity on shade-induced leaf senescence. Plant, Cell \& Environment, v.35, n.6, p.1084-1098, 2012. DOI: https:// doi.org/10.1111/j.1365-3040.2011.02474.x

DELLO-IOIO, R.; LINHARES, F.S.; SCACCHI, E.; CASAMITJANA-MARTINEZ, E.; HEIDSTRA, R.; COSTANTINO, P.; SABATINI, S. Cytokinins determine Arabidopsis root-meristem size by controlling cell differentiation. Current Biology, v.17, n.8, p.678-682, 2007. DOI: https://doi.org/10.1016/j.cub.2007.02.047

FARIA, D.V.; SIMÃO, M.J.; CIPRIANO, R.; WERNER, E.T.; SOARES, E.C.B.; AOYAMA, E.M.; GONTIJO, A.B.P.L. In vitro morphogenesis and micropropagation of Aechmea ramosa var. ramosa Mart. ex Schult. f. (Bromeliaceae) from leaf explants. In Vitro Cellular \& Developmental Biology - Plant, v.54, n.5, p.530-536, 2018. DOI: https://doi.org/10.1007/s11627-018-9907-0 
GENTILE, A.; FRATTARELLI, A.; NOTA, P.; CONDELLO, E.; CABONI, E. The aromatic cytokinin meta-topolin promotes in vitro propagation, shoot quality and micrografting in Corylus colurna L. Plant Cell, Tissue and Organ Culture, v.128, n.3, p.693-703, 2017. DOI: https://doi.org/10.1007/s11240-016-1150-y

JANEČKOVÁ, H.; HUSIČKOVÁ, A.; LAZÁR, D.; FERRETTI, U.; POSPÍŠIL, P.; ŠPUNDOVÁ, M. Exogenous application of cytokinin during dark senescence eliminates the acceleration of photosystem II impairment caused by chlorophyll b deficiency in barley. Plant Physiology and Biochemistry, v.136, p.43-51, 2019. DOI: https://doi.org/10.1016/j.plaphy.2019.01.005

JOCA, T.A.C.; OLIVEIRA, D.C.; ZOTZ, G.; WINKLER, U.; MOREIRA, A.S.F.P. The velamen of epiphytic orchids: variation in structure and correlations with nutrient absorption. Flora, v.230, p.66-74, 2017. DOI: https://doi. org/10.1016/j.flora.2017.03.009

JOHANSEN, D.A. Plant microtechnique, 2ed. Mc GrawHill, New York, 1940. 523p.

JUPA, R.; DIDI, V.; HEJÁTKO, J.; GLOSER, V. An improved method for the visualization of conductive vessels in Arabidopsis thaliana inflorescence stems. Frontiers in Plant Science, v.6, p.1-10, 2015. DOI: https:// doi.org/10.3389/fpls.2015.00211.

KOIKE, I.; TANIGUCHI, K.; SHIMOMURA, K.; UMEHARA, M. Dynamics of endogenous Indole-3-acetic acid and cytokinins during adventitious shoot formation in ipecac. Journal of Plant Growth Regulation, v.36, n.4, p.805-813, 2017. DOI: https://doi.org/ 10.1007/s00344017-9684-8

KOPEČNÝ, D.; KONČITÍKOVÁ, R.; POPELKA, H.; BRIOZZO, P.; VIGOUROUX, A.; KOPEČNÁ, M.; ZALABÁK, D.; ŠEBELA, M.; SKOPALOVÁ, J.; FRÉBORT, I.; MORÉRA, S. Kinetic and structural investigation of the cytokinin oxidase/dehydrogenase active site. The FEBS Journal, v.283, n.2, p.361-377, 2016. DOI: https://doi.org/10.1111/febs.13581

LARRABURU, E.E.; YARTE, M.E.; LLORENTE, B.E. Azospirillum brasilense inoculation, auxin induction and culture medium composition modify the profile of antioxidant enzymes during in vitro rhizogenesis of pink lapacho. Plant Cell, Tissue and Organ Culture, v.127, n.2, p.381-392, 2016. DOI: https://doi.org/10.1007/ s11240-016-1060-z

LEONG, T.M.; ANDERSON, J.M. Adaptation of the thylakoid membranes of pea chloroplasts to light intensities. II. Regulation of electron transport capacities, electron carriers, coupling factor (CF1) activity and rates of photosynthesis. Photosynthesis Research, v.5, n.2, p.117128. 1984. DOI: https://doi.org/10.1007/BF00028525.
LIM, H.; TANAKA, A.; TANAKA, R.; ITO, H. In Vitro enzymatic activity assays implicate the existence of the chlorophyll cycle in chlorophyll b-containing cyanobacteria. Plant and Cell Physiology, v. 60, n. 12, p. 2672-2683, 2019. DOI: https://doi.org/10.1093/pcp/pcz157

MACKOVÁ, H.; HRONKOVÁ, M.; DOBRÁ, J.; TUREČKOVÁ, V.; NOVÁK, O.; LUBOVSKÁ, Z.; MOTYKA, V.; HAISEL, D.; HÁJEK, T.; PRÁŠIL, I.T.; GAUDINOVÁ, A.; ŠTORCHOVÁ, H.; GE, E.; WERNER, T.; SCHMÜLLING, T.; VANKOVÁ, R. Enhanced drought and heat stress tolerance of tobacco plants with ectopically enhanced cytokinin oxidase/dehydrogenase gene expression. Journal of Experimental Botany, v.64, n.10, p.2805-2815, 2013. DOI: https://doi.org/10.1093/jxb/ert131

MAJDA, M.; ROBERT, S. The role of auxin in cell wall expansion. International Journal of Molecular Sciences, v.19, n.4, p.951, 2018. DOI: https://doi.org/10.3390/ ijms 19040951

MAMBRO, R.D.; RUVO, M.D.; PACIFICI, E.; SALVI, E.; SOZZANI, R.; BENFEY, F.N.; BUSCH, W.; NOVAK, O.; LJUNG, K.; PAOLA, L.D.; MARÉE, A.F.M.; COSTANTINO, P.; GRIENEISEN, V.A.; SABATINI, S. Auxin minimum triggers the developmental switch from cell division to cell differentiation in the Arabidopsis root. Proceedings of the National Academy of Sciences of the United States of America, v. 114, n. 36, p.E7641-E7649, 2017. DOI: https://doi.org/10.1073/pnas. 1705833114

MAMEDES-RODRIGUES, T.C.; BATISTA, D.S.; NAPOLEÃO, T.A.; FORTINI, E.A.; CRUZ, A.C.F.; COSTA, M.G.C.; OTONI, W.C. Regulation of cell wall development in Brachypodium distachyon in vitro as affected by cytokinin and gas exchange. Plant Cell, Tissue and Organ Culture, v.136, n.2, p.207-219, 2019. DOI: https://doi.org/10.1007/s11240-018-1506-6

MAO, J.; ZHANG, D.; MENG, Y.; LI, K.; WANG, H.; HAN, M. Inhibition of adventitious root development in apple rootstocks by cytokinin is based on its suppression of adventitious root primordia formation. Physiologia Plantarum, v.166, n.2, p.663-676, 2019. DOI: https://doi. org/10.1111/ppl.12817

MARTINS, J.P.R.; RODRIGUES, L.C.A.; CONDE, L.T.; GONTIJO A.B.P.L.; FALQUETO, A.R. Anatomical and physiological changes of in vitro-propagated Vriesea imperialis (Bromeliaceae) in the function of sucrose and ventilated containers. Plant Biosystems, v.154, n.1, p.87-99, 2020. DOI: https://doi.org/10.1080/11263504.2019.1635223

MARTINS, J.P.R.; RODRIGUES, L.C.A.; SANTOS, E.R.; BATISTA, B.G.; GONTIJO, A.B.P.L.; FALQUETO, A.R. Anatomy and photosystem II activity of in vitro grown Aechmea blanchetiana as affected by 1-naphthaleneacetic acid. Biologia Plantarum, v.62, n.2, p.211-221, 2018a. DOI: https://doi.org/10.1007/s10535-018-0781-8 
MARTINS, J.P.R.; SANTOS, E.R.; RODRIGUES, L.C.A.; GONTIJO A.B.P.L.; FALQUETO, A.R. Effects of 6-benzylaminopurine on photosystem II functionality and leaf anatomy of in vitro cultivated Aechmea blanchetiana. Biologia Plantarum, v.62, n.4, p.793-800. 2018b. https:// doi.org/10.1007/s10535-018-0822-3

MARTINS, J.P.R.; VERDOODT, V.; PASQUAL, P.; DE PROFT, M. Physiological responses by Billbergia zebrina (Bromeliaceae) when grown under controlled microenvironmental conditions. African Journal of Biotechnology, v.15, n.36, p.1952-1961, 2016. DOI: https://doi.org/10.5897/AJB2016.15584

MOSTOFA, M.G.; HOSSAIN, M.A.; SIDDIQUI, M.N.; FUJITA, M.; TRAN, L.S.P. Phenotypical, physiological and biochemical analyses provide insight into seleniuminduced phytotoxicity in rice plants. Chemosphere, v.178, p.212-223, 2017. https://doi.org/10.1016/j. chemosphere.2017.03.046

MURASHIGE, T.; SKOOG, F.A revised medium for rapid growth and biossays with tabacco tissue culture. Physiologia Plantarum, v.15, n.3, p.473-497, 1962. DOI: https://doi.org/10.1111/j.1399-3054.1962.tb08052.x

OZUDOGRU, E.A.; BENELLI, C.; DRADI, G.; LAMBARDI, M. Effect of culture container and carbohydrate content on in vitro slow growth storage of the cherry rootstock 'Gisela ${ }^{\circledR} 5$ '. Acta Physiologiae Plantarum, v.39, p.94, 2017. https://doi.org/10.1007/ s11738-017-2372-2

RASMUSSEN, A.; HOSSEINI, S.A.; HAJIREZAEI, M.R.; DRUEGE, U.; GEELEN, D. Adventitious rooting declines with the vegetative to reproductive switch and involves a changed auxin homeostasis. Journal of Experimental Botany, v.66, n.5, p.1437-1452, 2015. DOI: https://doi. org/10.1093/jxb/eru499

RESENDE, C.F.; RIBEIRO, C.; MENDES, G.C.; SOARES, C.Q.G.; BRAGA, V.F.; CRUZ, B.P.; FORZZA, R.C.; PEIXOTO, P.H.P. In vitro culture of Vriesea cacuminis L.B. Sm. (Bromeliaceae): na endemic species of Ibitipoca State Park, MG, Brazil. Iheringia Série Botânica, v.71, n.1, p.55-61, 2016.

RODRIGUES, L.C.A.; MARTINS, J.P.R.; ALMEIDA JÚNIOR, O.; GUILHERME, L.R.G.; PASQUAL, M.; CASTRO, E.M. Tolerance and potential for bioaccumulation of Alternanthera tenella Colla to cadmium under in vitro conditions. Plant Cell, Tissue and Organ Culture, v.130, n.3, p.507-519, 2017. https://doi.org/10.1007/s11240-017$1241-4$
ROSA, W.S.; MARTINS, J.P.R.; RODRIGUES, E.S.; RODRIGUES, L.C.A.; GONTIJO, A.B.P.L.; FALQUETO, A.R. Photosynthetic apparatus performance in function of the cytokinins used during the in vitro multiplication of Aechmea blanchetiana (Bromeliaceae). Plant Cell, Tissue and Organ Culture, v.133, n.3, p.339-350, 2018. DOI: https://doi.org/10.1007/s11240-018-1385-X

SANG, Y.L.; CHENG, Z.J.; ZHANG, X.S. Endogenous auxin biosynthesis and de novo root organogenesis. Journal of Experimental Botany, v.67, n.14, p.40114013, 2016. DOI: https://doi.org/10.1093/jxb/erw250

SATO, R.; ITO, H.; TANAKA, A. Chlorophyll b degradation by chlorophyll $\mathrm{b}$ reductase under high-light conditions. Photosynthesis Research, v.126, n.2-3, p.249-259, 2015. DOI: https://doi.org/10.1007/s11120-015-0145-6

SILVA, K.G.; SILVA, E.A.; FERREIRA, M.L.; KANASHIRO, S.; CAMARGO, P.B.; TAVARES, A.R. Gas exchange and chlorophyll $a$ fluorescence parameters of ornamental bromeliads. Ornamental Horticulture, v.23, n.4, p.400-406, 2017. DOI: https://doi.org/10.14295/ oh.v23i4.1064

SINGH, C.K.; RAJ, S.R.; JAISWAL, P.S.; PATIL, V.R.; PUNWAR, B.S.; CHAVDA, J.C.; SUBHASH, N. Effect of plant growth regulators on in vitro plant regeneration of sandalwood (Santalum album L.) via organogenesis. Agroforestry Systems, v.90, n.2, p.281-288, 2016. DOI: https://doi.org/10.1007/s10457-015-9853-3

VAN DIJCK, R.; DE PROFT, M.; DE GREEF, J. Role of ethylene and cytokinins in the initiation of lateral shoot growth in bromeliads. Plant Physiology, v.86, p.836-40, 1988. DOI: https://doi.org/10.1104/pp.86.3.836

VIEHMANNOVA, I.; CEPKOVA, P.H.; VITAMVAS, J.; STREBLOVA, P.; KISILOVA, J. Micropropagation of a giant ornamental bromeliad Puya berteroniana through adventitious shoots and assessment of their genetic stability through ISSR primers and flow cytometry. Plant Cell, Tissue and Organ Culture, v.125, n.2, p.293-302, 2016. DOI: https://doi.org/ 10.1007/s11240-016-0949-x

YANG, Y.N.; SAFAROVA, R.B.; PARK, S.Y.; SAKURABA, Y.; OH, M.H.; ZULFUGAROV, I.S.; LEE, C.B.; TANAKA, A.; PAEK, N.C.; LEE, C. H. Chlorophyll degradation and light-harvesting complex ii aggregate formation during dark-induced leaf senescence in Arabidopsis pheophytinase mutants. Journal of Plant Biology, v.62, n.1, p.27-38, 2019. DOI: https://doi. org/10.1007/s12374-018-0242-0 